\title{
Gambaran fungsi kognitif penderita parkinson di Poliklinik Saraf RSUP Prof. Dr. R. D. Kandou Manado
}

\author{
${ }^{1}$ Febrilya R. Tarukbua \\ ${ }^{2}$ Rizal Tumewah \\ ${ }^{3}$ Junita Maja P.S.
}

\begin{abstract}
${ }^{1}$ Kandidat Skripsi Fakultas Kedokteran Universitas Sam Ratulangi Manado
${ }^{2}$ Bagian Neurologi Fakultas Kedokteran Universitas Sam Ratulangi Manado Email: Freginatarukbua12153@yahoo.co.id
\end{abstract}

\begin{abstract}
Parkinson's disease (PD) is a neurodegenerative disease that can cause cognitive function impairment. This study aimed to obtain the cognitive function in Parkinson's patients at the Neurology Clinic Prof. Dr. R. D. Kandou Hospital Manado. This was a descriptive prospective study by using MMSE and MoCA Ina instrument. There were 31 patients of Parkinson's disease during November and December 2015. Of the 31 patients, 27 had cognitive function impairment. The highest percentages among them with cognitive function impairmentwere male gender, age group 60-71 years, high school education or of the same level. and had no job including retired male patients.
\end{abstract}

Keywords: Parkinson's disease, cognitive function

\begin{abstract}
Abstrak: Penyakit Parkinson ialah penyakit neurodegeneratif yang dapat disertai penurunan fungsi kognitif. Penelitian ini bertujuan untuk mendapatkan gambaran fungsi kongnitif pada pasien Parkinson di Poliklinik Saraf RSUP Prof. Dr. R. D. Kandou Manado. Jenis penelitian ini deskriptif prospektif dengan menggunakan instrumen penelitian MMSE dan MoCA Ina. Hasil penelitian mendapatkan 31 pasien Parkinson selang bulan November-Desember 2015. Terdapat 27 pasien dengan penurunan fungsi kognitif, terbanyak dijumpai pada jenis kelamin laki-laki, kelompok usia 61-70 tahun, tingkat pendidikan SMA/sederajat, dan yang sudah tidak bekerja termasuk laki-laki pensiunan.
\end{abstract}

Kata kunci: penyakit Parkinson, fungsi kognitif

Penyakit Parkinson adalah suatu kelainan fungsi otak yang secara patologik ditandai oleh degenerasi sel-sel saraf dalam otak yang disebut ganglia basal, hilangnya pigmentasi di substansia nigra, adanya inklusi sitoplasmik yang disebut Lewy bodies, serta penurunan dopamin di substansia nigra pars kompakta (SNC) dan korpus striatum. ${ }^{1}$ Penyakit Parkinson biasanya muncul pada usia 40-70, rata-rata diatas usia 55 tahun dan jarang di bawah usia 30 tahun atau setelah usia 80 tahun. $^{2}$ Lebih sering ditemukan pada laki-laki dibandingkan perempuan dengan rasio $3: 2{ }^{3}$

Penyakit ini menyebabkan gangguan pada fungsi motorik berupa kekakuan otot, tremor, rigiditas, perlambatan gerakan fisik dan bicara (bradikinesia), wajah Parkinson, instabilitias postural, serta demensia sehubungan dengan proses menua, faktor genetik, dan lingkungan. ${ }^{4}$

Beberapa tahun terakhir spektrum klinis penyakit Parkinson menjadi lebih luas, mencakup domain non motorik, termasuk kognitif. ${ }^{5}$ Degenerasi dari sistem neurotransmiter berperan penting terhadap fungsi kognitif penderita Parkinson. ${ }^{6}$ Fungsi kognitif adalah kemampuan seseorang dalam mengenal atau mengetahui mengenai benda atau keadaan, 
yang dikaitkan dengan pengalaman pembelajaran dan kapasitas inteligensi seseorang. Termasuk dalam fungsi kognisi ialah memori/daya ingat, konsentrasi/ perhatian, orientasi, kemampuan berbahasa, berhitung, visuospasial, fungsi eksekutif, dan abstraksi. ${ }^{7}$

Fungsi kognitif dari penderita parkinson dapat dinilai dengan menggunakan instrumen Mini Mental State Examination (MMSE) dan Monteral Cognitive Assesment versi Indonesia (Ina MoCA). ${ }^{8}$

\section{METODE PENELITIAN}

Jenis penelitian ini ialah deskriptif prospektif dan dilakukan pada bulan November dan Desember 2015 di Poliklinik Saraf RSUP Prof. Dr. R. D. Kandou Manado. Sampel ialah pasien yang didiagnosis menderita Parkinson dan dilakukan pemeriksaan langsung menggunakan instrumen MMSE dan Ina MoCA.

\section{HASIL PENELITIAN}

Pada bulan November-Desember 2015, didapatkan sebanyak 31 pasien penderita Parkinson yang memenuhi kriteria penelitian.

\section{Karakteristik sampel penelitian}

Tabel 1 memperlihatkan bahwa dari 31 pasien didapatkan pasien berjenis kelamin laki-laki lebih banyak menderita Parkinson dengan jumlah 16 pasien (51,6\%) dibandingkan perempuan berjumlah 15 pasien (48,4\%). Berdasarkan usia didapatkan umur 61-70 tahun paling rentan dengan penyakit Parkinson dengan jumlah 14 pasien (45,2\%) dibandingkan dengan umur $>80$ tahun dengan jumlah satu pasien (3,2\%). Berdasarkan tingkat pendidikan, didapatkan pendidikan SMA/sederajat yang paling tinggi persentasenya menderita Parkinson dengan jumlah 15 pasien (48,4\%) dibandingkan dengan pendidikan SD dengan jumlah 4 pasien (12,9\%). Berdasarkan pekerjaan, didapatkan pasien yang sudah tidak bekerja lebih banyak menderita Parkinson sebanyak 16 pasien
(51,6\%) dibandingkan dengan pasien yang bekerja sebagai ibu rumah tangga dengan jumlah 15 pasien $(48,4 \%)$.

Tabel 1. Distribusi penderita Parkinson berdasarkan jenis kelamin, usia, tingkat pendidikan, dan pekerjaan.

\begin{tabular}{lcc}
\hline Variabel & Jumlah & $\%$ \\
\hline Jenis Kelamin & & \\
$\quad$ Laki-laki & 16 & 51,6 \\
Perempuan & 15 & 48,4 \\
\hline Usia (tahun) & & \\
$50-60$ & 8 & 25,8 \\
$61-70$ & 14 & 45,2 \\
$71-80$ & 8 & 25,8 \\
$>80$ & 1 & 3,2 \\
\hline Tingkat pendidikan & & \\
SD & 4 & 12,9 \\
SMP & 5 & 16,2 \\
SMA & 15 & 48,4 \\
Sarjana & 7 & 12,6 \\
\hline Pekerjaan & & \\
IRT & 15 & 48,4 \\
Tidak bekerja & 16 & 51,6 \\
\hline
\end{tabular}

\section{Hasil pemeriksaan fungsi kognitif menggunakan MMSE}

Gambar 1 menunjukkan bahwa berdasarkan pemeriksaan MMSE dari 31 pasien diperoleh jumlah pasien dengan fungsi kognitif normal sebanyak 19 pasien (61\%) dan 12 pasien (39\%) dicurigai mengalami penurunan fungsi kognitif.

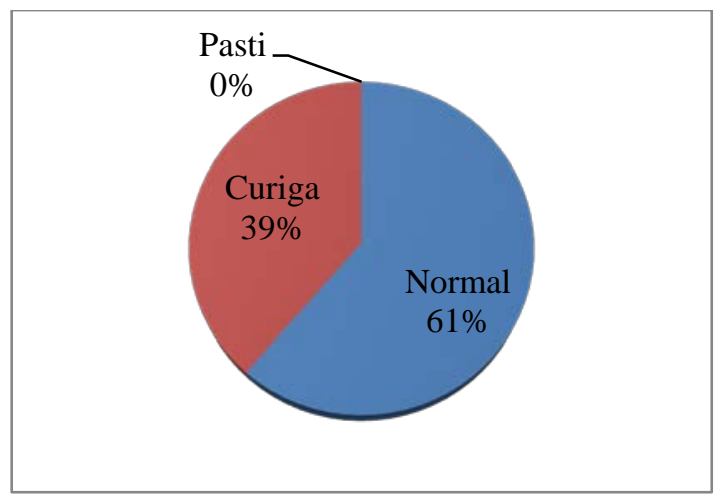

Gambar 1. Gambaran fungsi kognitif pasien penderita Parkinson berdasarkan hasil pemeriksaan MMSE 
Berdasarkan Tabel 1 dan Gambar 1, bila dikelompokkan berdasarkan gambaran fungsi kognitif, maka hasilnya dapat dilihat pada Tabel 2. Berdasarkan hasil pemeriksaan MMSE, pada gambaran jenis kelamin didapati 35,5\% laki-laki dan 29\% perempuan tergolong normal. Berdasarkan usia, didapatkan kelompok umur 60-71 yang paling banyak memiliki fungsi kogntif normal. Berdasarkan tingkat pendidikan, sebanyak 10 pasien (32,2\%) dengan pendidikan terakhir SMA/sederajat, masih memiliki fungsi kognitif normal. Berdasarkan pekerjaan, sebanyak 10 $(32,2 \%)$ pasien yang tidak bekerja, memiliki fungsi kognitif normal.

Tabel 2. Distribusi hasil MMSE Penderita parkinson berdasarkan Jenis kelamin, usia, tingkat pendidikan, dan pekerjaan

\begin{tabular}{lcccc}
\hline & \multicolumn{4}{c}{ MMSE } \\
\hline \multirow{2}{*}{ Variabel } & \multicolumn{2}{c}{$\mathrm{N}$} & \multicolumn{2}{c}{ Curiga } \\
& \multicolumn{4}{c}{ G. FK } \\
\cline { 2 - 5 } & $\mathrm{n}$ & $\%$ & $\mathrm{n}$ & $\%$ \\
\hline Jenis kelamin & & & & \\
L & 11 & 35,5 & 5 & 16,1 \\
$\mathrm{P}$ & 9 & 29 & 6 & 19,4 \\
\hline Umur & & & & \\
50-60 & 5 & 16,1 & 3 & 9,7 \\
$61-70$ & 9 & 29 & 5 & 16,1 \\
$71-80$ & 5 & 16,2 & 3 & 9,7 \\
$>80$ & 1 & 3,2 & 0 & 0 \\
\hline Pendidikan & & & & \\
SD & 0 & 0 & 4 & 12,9 \\
SMP & 4 & 12,9 & 1 & 3,2 \\
SMA & 10 & 32,2 & 6 & 19,4 \\
Sarjana & 7 & 22,6 & 0 & 0 \\
\hline Pekerjaan & & & & \\
IRT & 9 & 29 & 6 & 19,4 \\
Tidak bekerja & 10 & 32,2 & 6 & 19,4 \\
\hline Ket: G gangguan & FK & $=$ &
\end{tabular}

Ket: $\mathrm{G}=$ gangguan, $\mathrm{FK}=$ fungsi kognitif, $\mathrm{L}=$ laki-laki, $\mathrm{P}=$ perempuan, $\mathrm{T}=$ tidak

\section{Hasil pemeriksaan fungsi kognitif menggunakan MoCA Ina.}

Gambar 2 menunjukkan bahwa berdasarkan pemeriksaan MoCA Ina yang dilakukan pada 31 pasien penderita Parkinson diperoleh pasien dengan fungsi kognitif normal sebanyak 4 orang (13\%) sedangkan pasien dengan penurunan fungsi kognitif ringan berjumlah 12 orang (39\%) disusul dengan pasien yang mengalami penurunan fungsi kognitif sedang yaitu sebanyak 15 orang (48\%).

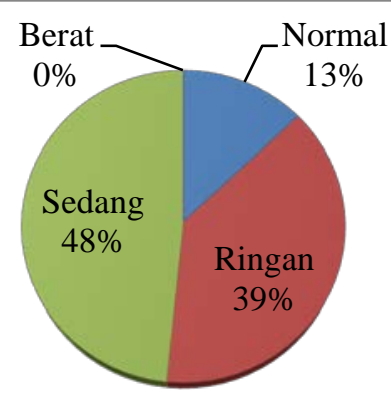

Gambar 2. Gambaran fungsi kognitif pasien penderita Parkinson berdasarkan hasil pemeriksaan MoCA Ina

Berdasarkan Tabel 1 dan Gambar 2, bila dikelompokkan berdasarkan gambaran fungsi kognitif, maka hasilnya dapat dilihat pada Tabel 3. Berdasarkan hasil pemeriksaan MoCA Ina, pada gambaran jenis kelamin didapatkan 48,8\% laki-laki dan $41,9 \%$ perempuan memiliki penurunan fungsi kognitif. Berdasarkan usia, didapatkan kelompok umur 60-71 yang paling banyak memiliki penurunan fungsi kognitif yaitu 5 pasien dengan penurunan fungsi kognitif ringan (16,1\%) dan 8 pasien dengan penurunan fungsi kognitif sedang (25,8\%). Berdasarkan tingkat pendidikan, SMA/sederajat juga lebih banyak mengalami penurunan fungsi kognitif baik ringan maupun sedang masing-masing sebanyak 7 (22,6\%) pasien. Berdasarkan pekerjaan, pasien yang tidak bekerja paling banyak memiliki penurunan fungsi kognitif ringan yaitu 9 (29\%) pasien dan sedang 6 $(19,4 \%)$ pasien.

\section{Gambaran penurunan fungsi kognitif penderita Parkinson}

Tabel 4 menunjukan bahwa berdasarkan hasil pemeriksaan MMSE dan MoCA Ina yang dilakukan pada 31 pasien penderita Parkinson ternyata semua pasien (100\%) penderita Parkinson mengalami kemunduran fungsi kognitif pada bagian memori dibandingkan dengan bagian 
abstrak berjumlah dua orang (6,5\%).

Tabel 3. Distribusi hasil MoCA Ina Penderita parkinson berdasarkan Jenis kelamin, umur, tingkat pendidikan, dan pekerjaan.

\begin{tabular}{|c|c|c|c|c|c|c|}
\hline & \multirow{2}{*}{\multicolumn{2}{|c|}{$\mathrm{N}$}} & \multicolumn{4}{|c|}{ Moca Ina } \\
\hline \multirow[t]{2}{*}{ Variabel } & & & \multicolumn{2}{|c|}{$\begin{array}{l}\text { G. FK } \\
\text { Ringan }\end{array}$} & \multicolumn{2}{|c|}{$\begin{array}{l}\text { G. FK } \\
\text { Sedang }\end{array}$} \\
\hline & $\mathrm{n}$ & $\%$ & $\mathrm{n}$ & $\%$ & $\mathrm{n}$ & $\%$ \\
\hline \multicolumn{7}{|l|}{ Jenis kelamin } \\
\hline L & 1 & 3,2 & 9 & 29 & 6 & 19,4 \\
\hline $\mathrm{P}$ & 3 & 9,2 & 5 & 16,1 & 8 & 25,8 \\
\hline \multicolumn{7}{|l|}{ Usia } \\
\hline 50-60 & 1 & 3,2 & 3 & 9,7 & 4 & 12,9 \\
\hline $61-70$ & 1 & 3,2 & 5 & 16,1 & 8 & 25,8 \\
\hline $71-80$ & 2 & 6,5 & 5 & 16,1 & 2 & 6,5 \\
\hline$>80$ & 0 & 0 & 1 & 3,2 & 0 & 0 \\
\hline \multicolumn{7}{|l|}{ Pendidikan } \\
\hline $\mathrm{SD}$ & 0 & 0 & 0 & 0 & 4 & 12,9 \\
\hline SMP & 1 & 3,2 & 1 & 3,2 & 3 & 9,7 \\
\hline SMA & 1 & 3,2 & 7 & 22,6 & 7 & 22,6 \\
\hline Sarjana & 2 & 6,5 & 5 & 16,1 & 0 & 0 \\
\hline \multicolumn{7}{|l|}{ Pekerjaan } \\
\hline IRT & 3 & 9,7 & 5 & 16,1 & 8 & 25,8 \\
\hline $\begin{array}{l}\text { Tidak } \\
\text { bekerja }\end{array}$ & 1 & 3,2 & 9 & 29 & 6 & 19,4 \\
\hline
\end{tabular}

Ket: $\mathrm{G}=$ gangguan, $\mathrm{F} . \mathrm{K}=$ fungsi kognitif, $\mathrm{L}=$ laki-laki, $\mathrm{P}=$ perempuan, $\mathrm{T}=$ tidak

Tabel 4. Gambaran penurunan fungsi kognitif penderita Parkinson

\begin{tabular}{lcc}
\hline $\begin{array}{l}\text { Penurunan } \\
\text { fungsi kognitif }\end{array}$ & $\begin{array}{c}\text { Jumlah } \\
\text { penderita } \\
\text { Parkinson }\end{array}$ & (\%) \\
\hline $\begin{array}{l}\text { Visuospasial/fungsi } \\
\text { eksekutif }\end{array}$ & 21 & 67,7 \\
Atensi & 18 & 58,1 \\
Bahasa & 7 & 22,6 \\
Memori & 31 & 100 \\
Penamaan & 3 & 9,7 \\
Orientasi & 7 & 22,6 \\
Abstrak & 2 & 6,5 \\
\hline
\end{tabular}

\section{BAHASAN}

Berdasarkan hasil penelitian didapatkan bahwa pasien laki-laki lebih banyak menderita Parkinson dibandingkan dengan perempuan. Hasil penelitian ini juga sesuai dengan penelitian yang dilakukan oleh.
Silitonga ${ }^{9}$ bahwa laki-laki (51,6\%) lebih banyak menderita Parkinson dibandingkan perempuan $(48,4 \%) .{ }^{9}$ Hasil pemeriksaan fungsi kognitif menggunakan MMSE (Tabel 2) mendapatkan 16,1\% pasien lakilaki penderita Parkinson mengalami penurunan fungsi kognitif. Berdasarkan pemeriksaan menggunakan Moca Ina (Tabel 3) penurunan fungsi kognitif lebih banyak didapatkan pada pasien laki-laki yaitu sebanyak 48,4\%. Dari kedua hasil ini didapatkan bahwa pemeriksaan MoCA Ina lebih dapat menunjukkan gambaran penurunan fungsi kognitif penderita Parkinson sehingga terlihat laki-laki penderita Parkinson lebih banyak mengalami penurunan fungsi kognitif dibandingkan dengan perempuan.

Berdasarkan usia pada penelitian ini dibagi atas 4 kelompok yaitu 50-60, 61-70, $71-80$, dan $>80$ tahun. Kelompok usia yang paling banyak menderita Parkinson yaitu pada 60-71 tahun. Hal ini sesuai dengan penelitian yang dilakukan oleh Trisnadewi ${ }^{2}$ di Poliklinik Neurologi RSUD Wangaya Denpasar selama bulan April-Juni 2014 pada 44 pasien bahwa penderita Parkinson paling banyak dialami oleh pasien berusia $>60$ tahun. Hal ini menunjukkan bahwa penyakit Parkinson menyerang lebih banyak pada orang dengan usia lebih dari 60 tahun. $^{2}$

Tabel 2 dan 3 memperlihatkan hasil pemeriksaan fungsi kognitif menggunakan MMSE dan MoCA Ina. Berdasarkan kelompok usia, didapatkan kelompok 60-71 tahun yang paling banyak mengalami penurunan fungsi kognitif dibandingkan dengan umur 50-60 tahun. Penyakit ini merupakan penyakit neurodegeneratif yang paling banyak didapatkan pada usia lanjut dengan awitan awal sekitar 60 tahun dan jarang pada umur dibawah 30 tahun. ${ }^{10} \mathrm{Hal}$ ini disebabkan karena pada usia lanjut terjadi proses penuaan yaitu proses menghilangnya secara perlahan-lahan jaringan yang berfungsi untuk memperbaiki dan mempertahankan struktur dan fungsi normalnya sehingga jaringan tersebut tidak dapat bertahan terhadap jejas. Hal ini sesuai dengan etiologi penyakit Parkinson yaitu 
dugaan adanya peran proses penuaan didasarkan pada penelitian bahwa pada penderita Parkinson terdapat suatu tanda reaksi mikroglial pada neuron yang rusak, sehingga disimpulkan bahwa proses penuaan merupakan faktor risiko yang mempermudah terjadinya proses degenerasi di SNC. ${ }^{1,4,11}$

Berdasarkan tingkat pendidikan, penderita Parkinson banyak ditemukan pada lulusan SMA/sederajat. Hal ini sesuai dengan penelitian yang dilakukan Ismaswati et al. ${ }^{8}$ di Poli Penyakit Saraf RSUP Dr. Wahidin Sudirohusodo, RSUD Labuang Baji dan RS Ibnu Sina pada bulan Januari 2013 sampai Mei 2013 yang melaporkan penyakit Parkinson terbanyak ditemukan pada lulusan SLTA (35,5\%). ${ }^{8}$ Pada Tabel 3, tingkat pendidikan SMA sederajat paling banyak dicurigai mengalami penurunan fungsi kognitif yaitu 19,4\% dan pada Tabel 5 SMA/sederajat juga lebih banyak mengalami penurunan fungsi baik ringan maupun sedang yaitu sebanyak 22,6\%.

Berdasarkan pekerjaan, penderita yang tidak bekerja termasuk laki-laki pensiunan paling banyak terkena Parkinson dibandingkan perempuan yang semuanya ibu rumah tangga. Hal ini dapat dipengaruhi oleh manifestasi klinik dari Parkinson berupa tremor, kekakuan otot, bradikinesia dan perlambatan gerakan fisik sehingga saat menderita penyakit Parkinson mengakibatkan terhambatnya dalam melaksanakan kegiatan-kegiatan yang seharusnya masih dapat dilakukan walaupun sudah pensiun. ${ }^{12}$

Berdasarkan Tabel 2 dan 3 pemeriksaan fungsi kognitif menggunakan MoCA Ina pada penderita yang sudah tidak bekerja lebih menunjukan banyak penurunan fungsi kognittif. Menurut Goldman et al. manifestasi penurunan kognitif pada penderita Parkinson merupakan hal yang sangat memengaruhi kualitas hidup. $^{13}$ Hasil pemeriksaan MMSE yang dilakukan pada 31 penderita Parkinson didapati sebanyak 61\% dinilai normal dan 31\% dicurigai mengalami penurunan fungsi kognitif (Gambar 1).
Pada hasil pemeriksaan MoCA Ina didapatkan penderita Parkinson dengan fungsi kognitif normal 13\%, gangguan fungsi kognitif ringan 39\% disusul dengan yang mengalami penurunan fungsi kognitif sedang sebanyak 48\% (Gambar 2). Hasil ini menunjukkan bahwa pemeriksaan fungsi kognitif dengan menggunakan MoCA Ina lebih dapat menunjukkan gambaran penurunan fungsi kognitif dibandingkan dengan pemeriksaan menggunakan MMSE. Dari penelitian Nazem et al. ${ }^{14}$ didapatkan bahwa lebih dari setengah subyek yang dinilai normal oleh MMSE memiliki gangguan kognitif pada skor MoCA-Ina.

Kelompok kerja The Society Abnormal Movement menyimpulkan berkaitan dengan fungsi kognitif pada penyakit Parkinson yaitu: atensi, visuospasial/fungsi eksekutif, bahasa, orientasi, abstrak, penamaan, dan memori. ${ }^{15}$ Pada Tabel 4 dapat dilihat bahwa semua penderita Parkinson mengalami penurnan fungsi kognitif pada bagian memori. Salah satu proses memori ialah retrival yang merupakan kemampuan untuk menyusun kembali dan mengeluarkan berbagai informasi yang telah tersimpan sebagai memori. Proses retrival terdiri atas recall yaitu kemampuan menggambarkan suatu informasi dengan kata-kata sendiri secara bebas. Penderita yang mengalami gangguan pada memori, lebih khususnya pada bagian recall tidak mampu mengulang 5 kata yang telah diucapkan sebelumnya seperti wajah, sutera, masjid, anggrek, merah. Hal ini menunjukkan bahwa pada penyakit Parkinson memori verbal lebih berpengaruh daripada memori visual. ${ }^{16}$

\section{SIMPULAN}

Dari hasil penelitian dan bahasan dapat disimpulkan bahwa penderita Parkinson yang mengalami penurunan fungsi kognitif terbanyak ialah laki-laki, usia 61-70 tahun, tingkat pendidikan terakhir terbanyak SMA/sederajat, dan yang sudah tidak bekerja.

Hasil pemeriksaan MMSE mendapatkan 12 penderita Parkinson dengan penurunan fungsi kognitif sedangkan hasil 
MoCA Ina mendapatkan 12 penderita Parkinson dengan gangguan fungsi kognitif ringan dan 15 penderita dengan gangguan fungsi kognitif sedang sehingga dari 31 penderita Parkinson terdapat 27 orang dengan penurunan fungsi kognitif.

\section{SARAN}

1. Perlu dilakukan pemeriksaan MMSE atau MoCA Ina pada penderita Parkinson yang datang di Poliklinik Saraf RSUP Prof Dr. R. D. Kandou Manado untuk mendeteksi dini adanya gangguan fungsi kognitif, sehingga dapat dilakukan tindakan pencegahan terjadinya gangguan dalam aktivitas setiap hari.

2. Penting bagi penderita parkinson untuk selalu melatih kognitif untuk menunjang kehidupan yang lebih baik dengan berkonsultasi ke dokter spesialis saraf.

3. Bagi keluarga penderita agar lebih memperhatikan dan membantu penderita dalam melakukan aktivitas setiap hari.

4. Diperlukan penelitian observasional dengan jangka waktu yang lebih panjang seperti kohort/case control untuk menilai perkembangan fungsi kognitif pasien penderita Parkinson.

\section{DAFTAR PUSTAKA}

1. Soetedjo, Martono HH. Gangguan neurologik pada usia lanjut. Martono $\mathrm{HH}$, Pranarka K, editors. Buku ajar Boedhi-Darmojo Geriatri (Ilmu Kesehatan Usia Lanjut) (4th ed). Jakarta: Balai penerbit FKUI, 2011; p. 3, 518.

2. Trisnadewi K. Kadar asam urat serum rendah meningkatkan resiko penyakit Parkinson [Tesis]. Denpasar: Program Studi Ilmu Biomedik (Program Pasca sarjana) Universitas Udayana; 2014.

3. Sjahrir H. Parkinson's Disease. Dementia dalam Parkinson's Disease \& Other Movement Disorder. Medan. Pustaka Press, 2007; p. 54-71.

4. Rahayu RA. Penyakit Parkinson. In: Sudoyo AW, Setiyohadi B, Alwi I, Marcellus SK, Setiati S, editors. Ilmu Penyakit Dalam (5th ed). Jakarta: InternaPublishing, 2009; p. 851-2.
5. Verbaan D, Marinus J, Visser $M$, van Rooden SM, Stiggelbout AM, Middelkoop HA, van Hilten JJ. Cognitive Impairment in Parkinson's. J Neurol Neurosug Psychiatry. 2007;78:1182-7

6. Lumbantobing SM. Neurogeriatri. Jakarta: Balai Penerbit FKUI, 2001; p. 10.

7. Wreksoatmodjo BR. Aktivitas kognitif mempengaruhi fungsi kognitif lanjut usia di Jakarta. CDK-224. 2015;42(1):8.

8. Ismawati, Muis A, Akbar M, Goysal Y, Cahyono K, Sartiono. Hubungan derajat klinis dan gangguan kognitif pada penderita Parkinson dengan menggunakan Monteral cognitive assessment versi Indonesia (MOCAINA) [Tesis]. Makassar: Bagian Ilmu Penyakit Saraf; 2014.

9. Silitonga R. Faktor-faktor yang berhubungan dengan kualitas hidup penderita penyakit Parkinson di Poliklinik Saraf RS Dr Kariadi. [Tesis]. Semaranag: Bagian Ilmu Penyakit Saraf Universitas Diponegoro; 2007.

10. Nuartha Ngr Bgs. Penyakit Parkinson dan parkinsonismus. Harsono DSS, editor. Kapita Selekta Neurologi (2nd ed). Yogyakarta: Gadjah Mada University press, 2009; p. 331.

11. Globe LI, Mark MH, Sage JI. Parkinson's Disease Handbook. New Jersey: American Parkinson Disease Association, 2009; p. 14-6.

12. Hendrik LN. Depresi berkolerasi dengan rendahnya kualitas hidup penderita Parkinson [Tesis]. Denpasar: Program Studi Biologi Molekuler (Program Pascasarjana) Universitas Udayana; 2013.

13. Goldman JG, Litvan I. 2011. Mild cognitive impairment in Parkinson's disease. Minerva Med. 2011;102(6): 441-59.

14. Nazem S, Siderowf AD, Duda JE, et al. Monteral Cognitive Assessment performance in patiens with Parkinson's disease with "normal" global cognition according to MiniMental-State-Examination score. J Am Geriatr Soc. 2009;57:304-8.

15. Fernandez RR, Casado JAM. Neuropsychological deficit in initial 
Jurnal e-Clinic (eCl), Volume 4, Nomor 1, Januari-Juni 2016

Parkinson's Disease. National University of distance Education (UNED) Journal. 2010;4:70-82.

16. Otero JL. Dementia with Parkinson disease: Clinical diagnosis, neuropsychological aspect and treatment. Dementia \& Neuropsychologia. 2008;2(4):261-6. 